\title{
Private Returns to Education in Urban Cameroon
}

\author{
Christian Zamo-Akono (Corresponding author) \\ Faculty of Economics and Management \\ University of Yaoundé II, Cameroon \\ E-mail: zchristy2@yahoo.fr \\ Roger Tsafack Nanfosso \\ Faculty of Economics and Management \\ University of Yaoundé II, Cameroon
}

Received: May 12, 2013 Accepted: May 28, 2013

doi:10.5296/ber.v3i2.3679 URL: http://dx.doi.org/10.5296/ber.v3i2.3679

\begin{abstract}
Earlier studies on the impact of education on earnings highlighted a declining pattern of the private returns in developing countries. However, recent research has argued that failing to account for the segmented structure of the labour market could be misleading. This study aims to estimate private returns to education in Cameroon, focusing on how they vary across the different segments of the Cameroon labour market. The data used in this study are drawn from the 2005 Employment and Informal Sector Survey, which is nationally representative and comprehensive survey providing information over 8,540 households and 38,599 individuals around the country. The estimation of wage equations corrected from selectivity bias reveals that there are convex rates of return to education in all the segments of the labour market. As far as the private sector is concerned, it is found that those who graduated from primary school earn no returns compared to those who never attended school. The fact that only degrees are rewarded on the Cameroon labour market evidences the existence of a sheepskin effect in Cameroon and may serve as a confirmation of the signalling role of education in this context.
\end{abstract}

JEL Classification: I21, J31, J40

Keywords: Returns to education, Labour market sectors, Earnings. 


\section{Introduction}

\subsection{Context}

Following independence in 1960, Cameroon recorded tremendous economic growth. The yearly average growth rate of per capita Gross Domestic Product (GDP) amounted to 4 percent during the period 1965-1976, 13 percent from 1977 to 1981, and 8 percent from 1982 to 1985 . By 1985, Cameroon was ranked among the middle-income countries, according to the World Bank taxonomy (De Monchy and Roubaud, 1991). During this "20-year golden age", the Government created many schools (primary and secondary) and instituted a partially free primary and secondary education in order to ensure access to education. As one of the crucial problems faced by Cameroon was the need for trained national cadres (especially for senior positions in the civil service), policy-makers held the view that the panacea would be for Government to create and run institutions of higher learning and thus make provision for the acquisition of skills necessary for national development. Cameroon created a variety of higher education institutions, among which one university and diverse state-owned professional schoolsi. During this period, unemployment was not a big issue, thanks to an ambitious development program of employment creation in the public sector, recruitments in state-owned enterprises, and development projects. Graduates of professional schools were assured of jobs in the public sector once admitted into the school; a practice that skewed the Cameroon labour market towards the public sector.

From 1986 to 1994, Cameroon faced a deep-seated crisis which led to a decline of the GDP by roughly six percent per annum between 1986 and 1993. Reforms engaged in order to comply with its commitments with the International Monetary Fund and the World Bank consisted in privatizing and restructuring public firms, dismissing in the public sector, suppressing civil servant advantages, and almost a 50 percent cut in per capita income during 1992-1993 (World Bank, 1996). The public sector, previously known as the main caterer in salaried and decent jobs, witnessed a significant decline in its share of total employment. This shrinking public sector employment, coupled with the incapacity of the private sector to absorb all the influx of job searchers in the labour market, induced the rise of unemployment. In 1992, there were over 76,500 job seekers in Cameroon (Aming and Awung, 2005). Along with low paying and poor working condition in both public and private sectors, many individuals were drained into the informal sector of the labour market. With 85.9 percent of employed workers in 1996 and 90.4 percent in 2005 (National Institute of Statistics, 1996; 2005), the informal sector emerged as the leading sector in terms of opportunities for employment. From 1995 onward, Cameroon regained a steady growth path and an annual GDP growth rate of roughly 4.5 percent (Emini, Cockburn, and Decaluwe, 2005). But despite the recovery, unemployment remained extremely pronounced, especially in urban areas. The 2005 Employment and Informal Sector Survey revealed that highest unemployment levels were observed in the two biggest agglomerations of Cameroon were the unemployment rates are $14.7 \%$ and $12.5 \%$, respectively for Yaoundé and Douala.

Despite a decline in individuals' employability due to the reduced capacity of the economy to absorb all the graduates of the educational system, large amounts of resources are still being 
invested in education by both Cameroon Government and Cameroonians. The landmark innovations of the 1993 reforms were the institution of a 50,000 CFA francs (CFAF) ${ }^{\text {ii }}$ registration fees for state-owned universities and the liberalization of the higher education sector. Tuition fees in private-owned institutions involved in the tertiary education range from CFAF650,000 to almost CFAF1,300,000 depending on the speciality chosen by the student (Tsafack, 2006). At the same time, the demand for education has kept increasing. While the Federal University started with a small enrolment of about 600 students, the student enrolment increased substantially as time went on up to 7000 in 1970, above 50000 by 1992 (Tafah-Edokat, 1989). According to the National Institute of Statistics, the student enrolment in State Universities and at the Catholic University of Central Africa (CUCA) was above 75000 during the 2001-2002 academic year, 91000 in 2004-2005, and above 105000 during the 2005-2006 academic year. It thus becomes interesting to investigate whether Cameroon educational system yields private returns that justify the resources invested in schooling. The main objective of this study is to estimate the private returns to education Cameroon. The outline of the paper is as follows. The next point reviews the literature, section two presents the methodology and provides a brief description of the data used in the study. Section three discusses the results and section four concludes.

\subsection{Private Returns to Education in the Literature}

According to the human capital theory, an individual's optimal investment in human capital calls for a consideration of both human and financial capacities, and the prospective utilization of the capital that is being accumulated (Mincer and Polachek, 1974). Consequently, the expectations regarding future family and market activities of individuals play an important role in the determination of the levels and forms of human capital investment. To the extent that labour market earnings are determined by the stock of human capital accumulated by individuals, a sequence of positive net investments results in an earning power that grows over the life cycle (Sackey, 2008). Consequently, educational attainments are thought to be a plausible cause of earnings differential between individuals. These ideas have given foundation to a huge number of studies on returns to schooling around the world.

Earlier studies were devoted to the analysis of the impact of length of schooling, labour market experience, and school quality on earnings. Psacharopoulos (1994) made an extensive survey of published studies on private returns to investments in education in many sub-Saharan African countries. He observed a declining pattern of the returns to education over time and found that the rate of return on primary education was 24 per cent, 18 per cent for secondary education and 11 per cent for higher education; he concluded that investments in primary education should be emphasized at the expense of higher education. These results were challenged by Bennell (1996) who revealed theoretical and empirical shortcomings in studies of individual rate of return to education in African countries. While undermining the credibility of Psacharopoulos' aggregate estimates for the continent as a whole, Bennell's arguments led to many other studies of sub-Saharan African countries who did not support Psacharopoulos' result of consistently higher returns to primary education than either secondary or higher education. For example, Manda and Bigsten (1998) and Liu (1998) analysed the impact of educational expansion and returns to schooling in Kenya and found that private return to 
secondary and tertiary education were high, but close to zero for primary education. Examining private returns to education in same country, Kimenyi et al. (2006) found that the returns to an additional year of schooling increased from about $8 \%$ for primary school to $23 \%$ for secondary school and then to $25 \%$ for university level of education. These results were confirmed in a number of sub-Saharan Africa countries by Appleton et al (1999), Bigsten et al (2000), Schultz (2004), and Aromolan (2004; 2006).

When it comes to the analysis of returns to schooling in Cameroon, there is relatively little empirical evidence. Among known studies, only Tafah-Edokat (1998) found that primary education gives the highest returns followed by secondary and tertiary education. He concluded like Psacharopoulos (1994) that the investment in primary education should be emphasized and that individuals willing to pursue further education should be made to bear a higher proportion of the cost of such education. His results suffer from the fact that his sample was mostly limited to civil servants. Although other studies find convex returns to education (Lanot and Muller, 1997; Bigsten et. al., 2000; Aming and Awung, 2005; Ewoudou and Vencatachellum, 2006), they do suffer from many shortcomings. The first one relates to the fact that some of the samples were not representative of the urban population diversity. For example, Bigsten et. al. (2000) worked on a sample of workers from 170 companies in the manufacturing sector and could not inform about returns in the formal or informal non-manufacturing sectors. While Lanot and Muller used data from a sample of 200 women in Yaoundé, Aming and Awung's results were based on the survey data collected in 1994 from rural and urban areas of Mfoundi, Moungo, Mezam, Benoue, Nyong and Soo, five subdivisions of only four regions of Cameroon. Second, results of some of these studies (principally Bigsten et. al., 2000; Aming and Awung, 2005) may not be reliable as most of them failed to account for the most notable characteristic of the Cameroon labour market that is, its structure in term of two homogeneous sectors (public and formal private) and a heterogeneous informal sector. Factors determining labour market decisions and outcomes are thought to be different from one sector to another and failing to account for these differences may result in biased estimates of the returns to education. Thus, this study advocates for an explicit modelling of the economic opportunities available to job seekers and the correction of selectivity bias in wage equations.

\section{Methodology.}

\subsection{Econometric Method}

To ascertain the returns to education, we use the standard and widely applied earnings function proposed by Mincer (1974). The methodology consists in estimating a semi-logarithmic equation, where $\log$ wages $(\ln W)$ are explained by education and individual economic and noneconomic characteristics $(X)$ that is:

$$
\ln W_{i}=\beta_{0}+\beta_{1} \operatorname{Prim}_{i}+\beta_{2} \text { Second }_{i}+\beta_{3} \text { Univ }_{i}+\sum_{j} \alpha_{j} X_{j i}+\varepsilon_{i}
$$

with, $\beta_{0}$ representing an intercept term, $\alpha_{j}$ an unknown parameter associated to variable $X_{j}$, 
and $\varepsilon$ the random disturbance term.

Returns to education being dependent of the proportion of qualified individuals that are applying for a job on the labour market (Angrist, 1995), the increasing production of high skilled individuals in Cameroon is likely to have induced a filtering down process in which low paying job attract overqualified individuals. In such a context and for a given labour market experience, education may loose its explanatory power on the wages. Hypothesizing the existence of a "parchment effect" on the Cameroon urban labour market, we include dummy variables representing the highest degree obtained by an individual and obtain the following second equation.

$$
\ln W_{i}=\beta_{0}+\beta_{1} \operatorname{Prim}_{i}+\beta_{2} \text { Second }_{i}+\beta_{3} \text { Univ }_{i}+\sum_{k=1}^{8} \mu_{k} \text { Degree }_{k i}+\sum_{j} \alpha_{j} X_{j i}+\varepsilon_{i}
$$

Due to the fact that wages are unobserved for individuals whose market pay is lower than their reservation wage, the analysis of earnings is potentially affected by a non-random selection of individuals into the labour market. In such a setting, earnings are jointly determined with labour force participation and any analysis that ignores the process of labour force participation is potentially subject to selection bias. To correct for such a bias, the two-step estimation method developed by Lee (1983) and Trost and Lee (1984) is adopted. In the first stage, the selection into the labour market is estimated. As far as the Cameroon labour market is concerned, individuals face four mutually exclusive labour market outcomes: unemployed $(1=0)$ the reference group; employed in the public (including parastatal companies) sector $(l=1)$, in the private formal sector $(l=2)$, and in the informal sector $(l=3)$. The probability that individual $i$ has outcome $l$ is given by a multinomial logit:

$$
p_{l}=\exp \left(\gamma_{l}^{\prime} Z_{i}\right) / \sum_{l=0}^{3} \exp \left(\gamma_{l}^{\prime} Z_{i}\right)
$$

The choice of or selection into one of these sectors is thought to depend on a vector of explanatory variables $(Z)$ capturing an individual's perceived net differentials in wages between them, tastes and preferences, as well as human capital and other characteristics; $\gamma$ represents a vector of associated unknown parameters to estimate. From these estimates, we

construct the selection term (Mills' ratio) for the alternative $l$ as $\lambda_{l}=\phi\left(\gamma_{l}^{\prime} Z_{i}\right) / \Phi\left(\gamma_{l}^{\prime} Z_{i}\right)$; $\phi$ being the normal density function and $\Phi$ the normal distribution function. In the second stage, the estimated $\lambda_{l}$ is included among the explanatory variables of the wage equations. The implied sector wage equation 4 is estimated by OLS for $l=1 ; 2 ; 3$.

$$
\ln W_{i}=\beta_{0}+\beta_{1} \text { Prim }_{i}+\beta_{2} \text { Second }_{i}+\beta_{3} \text { Univ }_{i}+\sum_{k=1}^{8} \mu_{k} \text { Degree }_{k i}+\sum_{j} \alpha_{j} X_{j i}+\lambda_{l}+\varepsilon_{i}
$$

With this specification, we compute both total and marginal returns to education. Total return to a given level of education (or degree) is defined as the mean difference between the wage of 
someone who achieved level $j$ (obtained degree $k$ ) and the wage of the other one who didn't go to school (obtained any degree). It is given by:

$$
t r_{\text {level-J }}=\exp \left(\beta_{j}\right)-1 \text { and } t r_{\text {deg } r e e-K}=\exp \left(\beta_{k}\right)-1 .
$$

Following Kimenyi et al. (2006), the marginal return to education was defined as returns that accrue to an additional year of schooling. This value is computed by dividing the difference between the coefficients of adjacent schooling levels (degrees) by their differences in years of schooling. Letting $R$ represent the rate of return and $S$ the years of schooling, the rate of return to an additional year of schooling for a given level and for a given degree are measured respectively for the level of education and the highest degree as follows:

$$
m r_{\text {level } J}=\frac{\exp \left(\beta_{j}-\beta_{j-1}\right)-1}{\left(S_{\text {level } J}-S_{\text {level } J-1}\right)} \text { and } m r_{\text {deg ree K }}=\frac{\exp \left(\mu_{k}-\mu_{k-1}\right)-1}{\left(S_{\text {deg ree } K}-S_{\text {deg ree K-1 }}\right)}
$$

To determine the years of schooling (S), Sackey (2008) used the statutory number of years for the completion of any given level of schooling, assuming a homogenous educational system. As far as our study is concerned, there's a need to point out that Cameroon educational system is a mixture of the Anglophone and the Francophone systems which differ in some respects especially on the statutory duration of studies in both the primary and secondary levels. For instance in the Anglophone system, primary education lasts for seven years and leads to the First School Leaving Certificate (FSLC). The first level of secondary education lasts for five years and leads to the General Certificate of Education Ordinary level (GCE-OL) and higher schools offer two-year courses leading to the GCE Advanced level (GCE-AL). As far as the Francophone system is concerned, six years in primary education lead to the French version of the FLSC, five more years in the first cycle of secondary education lead to the French GCE-OL, and finally three years' study in the upper secondary lead to the GCE-AL named BACCALAURÉAT ${ }^{\mathrm{iii}}$.Thus, to get to the tertiary level of education, the Anglophone system involves a sequence of seven, five and two years, while the Francophone system requires a sequence of six, four and three years. University level studies depict similar differences between the faculties ${ }^{\text {iv }}$. Consequently, unlike Sackey (2008), our measure of the years of schooling (S) must allow to account for both heterogeneities inside the system, grade repetition, examination failures, and school dropout before stage completion. For these reasons, years of schooling are derived from information on the highest class successfully completed by attaching the modal number of years to educational levels and degrees.

\subsection{Data Source}

The data used in this study are drawn from the 2005 Employment and Informal Sector Survey (EISS) which is a nationally representative and comprehensive survey providing information over 8,540 households and 38,599 individuals around the country. Information covers socioeconomic characteristics, employment status and characteristics, and some family background indicators. Of particular interest is information on variables, which might permit meaningful separations of the data by type-of-employment and labour market sector. The 
survey also includes information on the industry of employment and occupation and on a variety of income sources, including weekly earnings and wages analyzed in this study. The analysis of returns to education concentrates only of salaried workers. The rationale is that, revenues generated from self-employed individuals' activities do not simply remunerate labour, but also capital. Considering the fact that there's no information on how to dissociate these components, it is better to exclude these individuals from the analysis. The sample used in this study included only individuals in the working age group 15 to 65 years, who were full-time employees, and lived in Cameroon urban areas. It consisted of 13,104 observations covering individuals both in the public (871), private formal (898), informal (2458) sectors, as well as unemployed (5420) ones. Sample modal numbers of years are 6, 9 and 16 respectively for those who have the primary, the secondary and the tertiary levels of education ${ }^{\mathrm{v}}$. While considering the highest degree obtained, we have 6 for the Primary school certificate (FLSC), 10 for the first level secondary school diploma (GCE-OL), 12 for the PROBATION degree, 13 for the GCE-AL, 15 for the BTS degree, 16 BACHELOR degree, 18 for the MASTER and upper degrees (Master/PhD).

Table 1 presents means and standard deviations for the main variables of the study. As can be seen on it, there are differences between those who are considered as having a given level of education and the proportion of individuals having at least the lowest degree of this level. For example, $52.9 \%$ of civil servants have the secondary level of education but only $46.5 \%$ hold at least a GCE-OL. These differences are due to grade repetition, examination failures, and school dropout before stage completion. Further, there are important differences in educational attainment by sector of employment. While $88.6 \%$ of individuals working in the public sector have at least the secondary level of education, in the formal private and informal sectors the analogous figures are, respectively, $78.9 \%$ and $53.8 \%$. As far as degrees are concerned, the proportions of individuals who hold a university degree are $40.3 \%, 18.9 \%$, and $2.44 \%$ respectively in the public, formal private and informal sectors. The higher proportion of university graduates in civil servant jobs than in private sector ones is partly attributable to the fact that access to many Government jobs require a higher education degree. Observed differences in education are reflected in wage differences. Actually, sizeable earnings differentials in favour of public sector employees relative to formal private and informal sectors workers are found across labour market sectors. The average $\log$ (wage) is 11.65 in the public sector, 11.279 in the formal private sector, and 10.253 in the informal sector. A group mean comparisons tests reveals that public sector earnings are higher than both formal private and informal sectors wages. The earnings gap in favour of the public sector may be either due to higher economic returns to human capital in the public sector, or to differences in personal or job characteristics (education, experience or occupations) between employees across the labour market sectors. Consistent with the notion that rewards in the public sector are less variable, the standard deviation of these variables is lower in the public than in the private sector. 
Table 1. Sample characteristics for basic variables

\begin{tabular}{|l|c|c|c|c|c|c|}
\hline \multirow{2}{*}{ Variables } & \multicolumn{2}{|c|}{ Public sector } & \multicolumn{2}{c|}{ Formal private sector } & \multicolumn{2}{c|}{ Informal sector } \\
\cline { 2 - 7 } & Mean & $\begin{array}{c}\text { Standard } \\
\text { deviation }\end{array}$ & Mean & $\begin{array}{c}\text { Standard } \\
\text { deviation }\end{array}$ & Mean & $\begin{array}{c}\text { Standard } \\
\text { deviation }\end{array}$ \\
\hline Education variables & & & & & & \\
Level of education & 0.106 & & 0.191 & & 0.393 & \\
Primary school dummy & 0.529 & & 0.567 & & 0.502 & \\
Secondary school dummy & 0.357 & & 0.222 & & 0.036 & \\
Tertiary school dummy & & & & & & \\
Highest degree obtained & 0.190 & & 0.285 & & 0.491 & \\
Primary school certificate & 0.182 & & 0.224 & & 0.131 & \\
First Level Secondary school & 0.071 & & 0.066 & & 0.042 & \\
diploma & 0.212 & & 0.146 & & 0.040 & \\
Probation degree & 0.050 & & 0.056 & & 0.006 & \\
High School certificate & 0.121 & & 0.065 & & 0.013 & \\
BTS degree & 0.111 & & 0.060 & & 0.005 & \\
Bachelor/Licence degree & 12.351 & 3.387 & 10.835 & 4.025 & 6.739 & 3.806 \\
Master and upper degrees & & & & & & \\
Years of schooling & 11.650 & 0.766 & 11.279 & 0.863 & 10.253 & 0.774 \\
Other variables & 39.640 & 8.823 & 33.726 & 9.493 & 26.879 & 9.399 \\
Log(wage) & 6.717 & 6.797 & 5.0634 & 5.580 & 3.093 & 4.360 \\
Age & 156.436 & 31.387 & 202.841 & 64.462 & 184.019 & 87.006 \\
Experience & 0.437 & & 0.197 & & 0.077 & \\
Monthly hours of work & & & & & & \\
Migration status & & & & & \\
\hline
\end{tabular}

\section{Results and Discussion}

Table 2 provides the results from estimating earnings functions for the public, formal private and informal sectors in Cameroon for the two specifications under consideration. Globally, all the wage equations are statistically significant with an R-squared which is around $34 \%$ in the public sector, $40 \%$ in the formal private sector around $25 \%$ the informal sector; these statistics means that the model is better fitted to explain wages of public and formal private sectors workers. A first noteworthy result is that a large part of the variance of earnings reflects unobservable factors that are not captured in the regression equations. Unlike Ewoudou and Vencatachellum (2006) who got a significant selection term only in the public sector, the sample selection correction terms are significant and negative for all the labour market sectors, meaning that it is important in the case of Cameroon to explicitly model selection into employment when estimating earning functions. If we hypothesize that people choose their status of employment in a way which maximizes their earnings potential, then we should observe positive selection. One interpretation of the negative selection into employee status is therefore that there exist some unobserved factors that increase one's probability to be employed but also contribute to the likelihood that a person will earn a below average wage. 
Table 2. Estimated earnings coefficients.

\begin{tabular}{|c|c|c|c|c|c|c|}
\hline \multirow[b]{2}{*}{ Variables } & \multicolumn{2}{|c|}{ Public sector } & \multicolumn{2}{|c|}{ Private sector } & \multicolumn{2}{|c|}{ Informal sector } \\
\hline & 1 & 2 & 1 & 2 & 1 & 2 \\
\hline Age & $\begin{array}{c}0.0242 * * * \\
(6.26)\end{array}$ & $\begin{array}{c}0.0239 * * * \\
(6.42)\end{array}$ & $\begin{array}{c}0.0214 * * * \\
(6.32)\end{array}$ & $\begin{array}{c}0.0195 * * * \\
(5.99)\end{array}$ & $\begin{array}{c}0.0219 * * * \\
(9.08)\end{array}$ & $\begin{array}{c}0.0199 * * * \\
(8.55)\end{array}$ \\
\hline Experience & $\begin{array}{c}0.0183 * \\
(1.67)\end{array}$ & $\begin{array}{c}0.0180^{*} \\
(1.67)\end{array}$ & $\begin{array}{c}0.0547 * * * \\
(3.64)\end{array}$ & $\begin{array}{c}0.0547 * * * \\
(3.59)\end{array}$ & $\begin{array}{c}0.0396 * * * \\
(4.26)\end{array}$ & $\begin{array}{c}0.0407 * * * \\
(4.56)\end{array}$ \\
\hline Experience squared & $\begin{array}{c}-0.0009^{* *} \\
(-1.98)\end{array}$ & $\begin{array}{c}-0.0008^{* *} \\
(-1.96)\end{array}$ & $\begin{array}{c}-0.0018^{* *} \\
(-2.46)\end{array}$ & $\begin{array}{c}-0.0018 * * * \\
(-2.38)\end{array}$ & $\begin{array}{c}-0.0013 * * * \\
(-3.14)\end{array}$ & $\begin{array}{c}-0.0013^{* * * *} \\
(-3.47)\end{array}$ \\
\hline $\begin{array}{l}\text { Monthly hours of } \\
\text { work }\end{array}$ & $\begin{array}{c}0.0017 * * \\
(2.21)\end{array}$ & $\begin{array}{c}0.0018^{* *} \\
(2.29)\end{array}$ & $\begin{array}{c}0.0004 \\
(1.09)\end{array}$ & $\begin{array}{l}0.0005 \\
(1.52)\end{array}$ & $\begin{array}{l}0.0021 * * * \\
\quad(9.36)\end{array}$ & $\begin{array}{c}0.0022 * * * \\
(9.90)\end{array}$ \\
\hline Migration status & $\begin{array}{c}0.1895 * * * \\
(4.54)\end{array}$ & $\begin{array}{c}0.1821 * * * \\
(4.37)\end{array}$ & $\begin{array}{c}0.2245^{* * *} \\
\quad(3.42)\end{array}$ & $\begin{array}{c}0.1941 * * * \\
(3.05)\end{array}$ & $\begin{array}{c}0.1092 * \\
(1.96)\end{array}$ & $\begin{array}{c}0.1022 * \\
(1.86)\end{array}$ \\
\hline $\begin{array}{l}\text { Level of education } \\
\text { dummies }\end{array}$ & $\begin{array}{c}0.5597 * * \\
(2.01)\end{array}$ & $\begin{array}{l}0.2806 \\
(0.91)\end{array}$ & $\begin{array}{r}0.1657 \\
(1.19)\end{array}$ & $\begin{array}{l}0.0796 \\
(0.53)\end{array}$ & $\begin{array}{c}0.1588^{* *} \\
(2.03)\end{array}$ & $\begin{array}{l}0.1311 \\
(1.61)\end{array}$ \\
\hline $\begin{array}{l}\text { Primary school } \\
\text { dummy }\end{array}$ & $\begin{array}{c}0.8776^{* * *} \\
\quad(3.16)\end{array}$ & $\begin{array}{l}0.3927 \\
(1.21)\end{array}$ & $\begin{array}{c}0.4889 * * * \\
\quad(3.39)\end{array}$ & $\begin{array}{l}0.1769 \\
(1.04)\end{array}$ & $\begin{array}{l}0.5646^{* * * *} \\
\quad(6.55)\end{array}$ & $\begin{array}{c}0.4019 * * * \\
\quad(4.03)\end{array}$ \\
\hline $\begin{array}{l}\text { Secondary school } \\
\text { dummy }\end{array}$ & $\begin{array}{c}1.2694 * * * \\
(4.21)\end{array}$ & $\begin{array}{l}0.5499 \\
(1.56)\end{array}$ & $\begin{array}{c}1.1359 * * * \\
(6.73)\end{array}$ & $\begin{array}{c}0.1012 \\
(0.46)\end{array}$ & $\begin{array}{c}1.2189 * * * \\
(7.27)\end{array}$ & $\begin{array}{c}0.2794 \\
(0.96)\end{array}$ \\
\hline & & $0.3794 * * *$ & & 0.1358 & & 0.0390 \\
\hline Tertiary school & & $(2.38)$ & & $(1.51)$ & & $(0.80)$ \\
\hline dummy & & $\begin{array}{c}0.4765 * * * \\
(2.79)\end{array}$ & & $\begin{array}{c}0.3082 * * * \\
(2.77)\end{array}$ & & $\begin{array}{c}0.2390 * * * \\
\quad(3.40)\end{array}$ \\
\hline $\begin{array}{l}\text { Highest degree } \\
\text { dummies }\end{array}$ & & $\begin{array}{c}0.5142^{* * *} \\
\quad(2.80)\end{array}$ & & $\begin{array}{l}0.4353 * * * \\
\quad(3.22)\end{array}$ & & $\begin{array}{c}0.3332 * * * \\
(3.29)\end{array}$ \\
\hline FLSC & & $\begin{array}{c}0.6493 * * * \\
(3.76)\end{array}$ & & $\begin{array}{c}0.5758 * * * \\
\quad(4.58)\end{array}$ & & $\begin{array}{c}0.3960 * * * \\
(3.83)\end{array}$ \\
\hline GCE-OL & & $\begin{array}{c}0.7724 * * * \\
\quad(3.55)\end{array}$ & & $\begin{array}{c}1.0822 * * * \\
(5.61)\end{array}$ & & $\begin{array}{c}0.5426 \\
(1.43)\end{array}$ \\
\hline PROBATION & & $0.6746^{* * *}$ & & $0.8702 * * *$ & & $1.2524 * * *$ \\
\hline degree & & $(3.37)$ & & $(4.51)$ & & $(4.18)$ \\
\hline GCE-AL & & $\begin{array}{c}0.9252 * * * \\
(4.73)\end{array}$ & & $\begin{array}{c}1.4887 * * * \\
(7.23)\end{array}$ & & $\begin{array}{c}1.4090 * * * \\
(4.08)\end{array}$ \\
\hline BTS degree & $\begin{array}{c}-1.1017 * * \\
(-2.13)\end{array}$ & $\begin{array}{c}-0.8818^{*} \\
(-1.73)\end{array}$ & $\begin{array}{c}-2.1987 * * * \\
(-3.04)\end{array}$ & $\begin{array}{c}-1.9442 * * \\
(-2.80)\end{array}$ & $\begin{array}{c}-1.1746 * * * \\
(-3.75)\end{array}$ & $\begin{array}{c}-1.1588 * * * \\
(-3.78)\end{array}$ \\
\hline $\begin{array}{l}\text { BACHELOR } \\
\text { degree }\end{array}$ & $\begin{array}{c}10.0179 * * * \\
(16.32)\end{array}$ & $\begin{array}{c}9.8414 * * * \\
(16.28)\end{array}$ & $\begin{array}{c}11.1954 * * * \\
(17.21)\end{array}$ & $\begin{array}{c}11.0404 * * * \\
(17.80)\end{array}$ & $\begin{array}{c}9.2179 * * * \\
(49.39)\end{array}$ & $\begin{array}{c}9.2614 * * * \\
(51.43)\end{array}$ \\
\hline $\begin{array}{l}\text { MASTER and upper } \\
\text { degrees }\end{array}$ & $\begin{array}{c}49.20 \\
0.0000\end{array}$ & $\begin{array}{c}31.81 \\
0.0000\end{array}$ & $\begin{array}{c}53.88 \\
0.0000\end{array}$ & $\begin{array}{c}35.67 \\
0.0000\end{array}$ & $\begin{array}{c}44.64 \\
0.0000\end{array}$ & $\begin{array}{c}30.35 \\
0.0000\end{array}$ \\
\hline
\end{tabular}




\section{Macrothink}

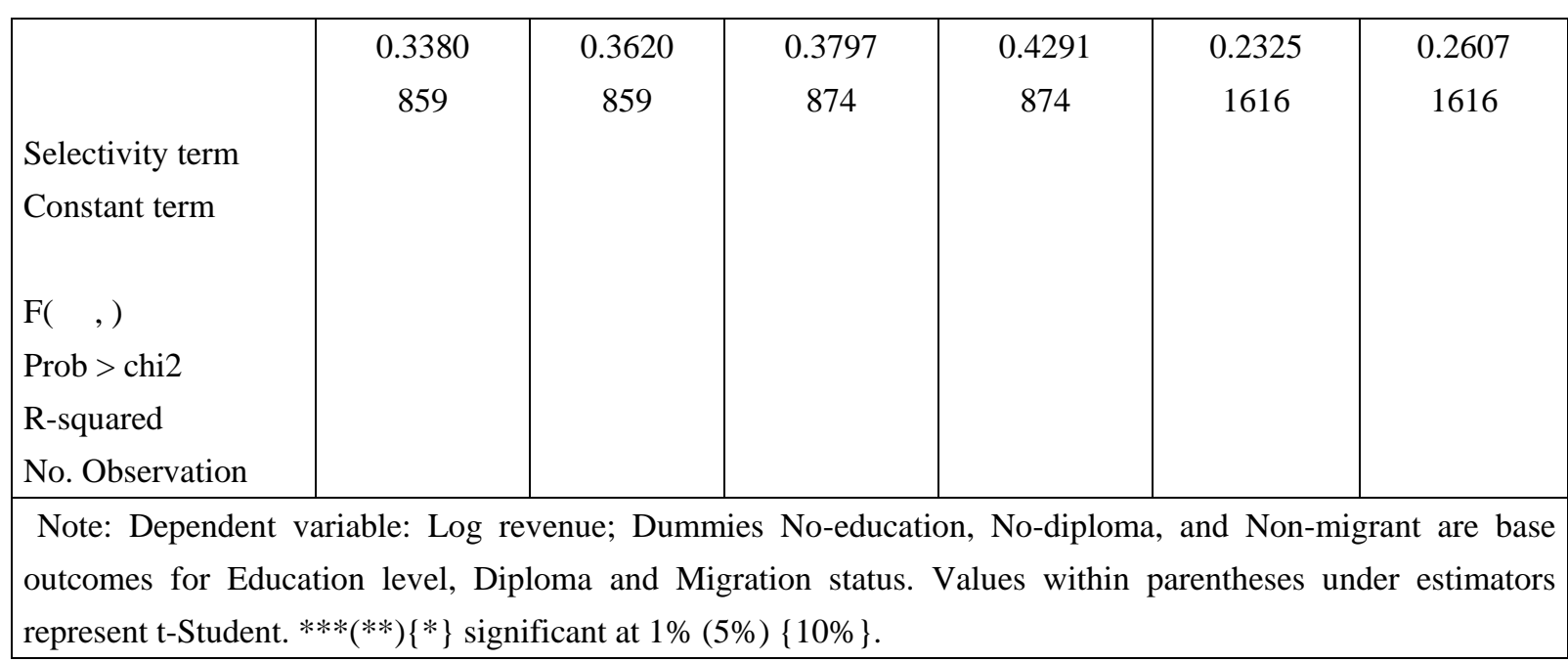

Results show that the association between monthly wages and monthly working hours is positive and significant in the public and informal sectors. There is a non-linear relationship between earnings and experience is reflected in the coefficient on the experience variable bearing a positive sign, while the experience squared variable has a negative sign. Following Mincer's (1974) and Card's (1999) idea, one can interpret this result as an indication that people increase their productivity while working through the learning by doing process an that earnings increase with an increasing rate at the beginning of the carrier and with a decreasing rate through the end of the carrier. One more year of experience increases log (wage) by about $1.81 \%$ in the public sector, $5.62 \%$ in the formal private sector, and $4.15 \%$ in the informal sector $^{\mathrm{vi}}$. According to the microeconomic theory of migration, individuals' migration decisions are the outcome of human capital investment decisions (Sjaastad, 1962) and are aimed at securing either jobs or better-paying jobs. This view was confirmed by Tsafack and Zamo (2009) who gave evidence of significant wage differentials in favor of migrants in urban Cameroon. This study does dive into that result by explicitly highlighting that returns to migration are around $19.97 \%$ in the public sector, $21.42 \%$ in the formal private sector and $10.76 \%$ in the informal sector.

In line with findings in the literature, our results show that earnings rise with higher levels of education. Taking the first specification and irrespective of the labour market sector, returns to education are convex and the statistical significance becomes stronger with higher levels of schooling. The profile of the convexity of the returns to education are close in magnitude to what was estimated for Turkey in the informal sector (Tansel, 1999), for Cameroon private sector (Ewoudou and Vencatachellum, 2006), and for Ghanaian male workers (Sackey, 2008). As Benhayoun and Bazen (1995) observed in Morocco, the returns to the level of education are overestimated when omitting the highest degree obtained by the individual. For instance, returns to the tertiary level of education are lowered and become non significant in all the labour market sectors. This result evidences the existence the of a sheepkin effect in the Cameroon urban labour market, that is the fact that part of the returns to education is due to the influence of degrees on wages. This may be interpreted as a confirmation of Arrow's "filter theory" according to which the main function of education is not to increase people's productivity, as postulated in the human capital theory, but to filter candidates with the most 
impressive characteristics.

Table 3 summarizes the private rates of return to education in the different labour market sectors. It shows that returns to degrees obtained before university are greater in the public sector. Monthly wages differentials between the omitted class of non-graduated and individual with a GCE-Ordinary level are around $61.04 \%$ in the public sector, 36.09 in the formal private, and $24.99 \%$ in the informal sectors. For those who hold a GCE-AL, the same wage differentials are around $91.42 \%$ in the public sector, 77.85 in the formal private, and $48.58 \%$ in the informal sectors. Thus, the major pattern that emerges from these results is that, it is more beneficial for those with the secondary level of education to work in the sector formal (public or private) than in informal sector. As far as university degrees are concerned, returns are greater in the private sector. For instance, the BACHELOR degree raises wages by approximately $138.73 \%$ in the formal private sector and only by $96.32 \%$ in the public sector. It is worth nothing that university degrees significantly affect pay in the informal sector. Still, coefficient estimates for different degrees may not be reliable as there are very few observations in some of the cells. For instance, there are only 15 observations in the informal sector for the Master and upper degrees. Therefore, the results concerning informal sector wage equations should be interpreted cautiously.

Table 3. Estimated return rates to degrees (second specification)

\begin{tabular}{|l|c|c|c|c|c|c|}
\hline \multirow{2}{*}{ Variables } & \multicolumn{2}{|c|}{ Public sector } & \multicolumn{2}{c|}{ Private sector } & \multicolumn{2}{c|}{ Informal sector } \\
\cline { 2 - 7 } FLSC & total & marginal & total & marginal & total & marginal \\
\hline GCE-OL & $0.4614 * *$ & --- & 0.1454 & --- & 0.0397 & -- \\
PROBATION degree & $0.6104 * *$ & 0.0254 & $0.3609 * * *$ & 0.0470 & $0.2499 * * *$ & 0.0553 \\
GCE-AL & $0.6723 * *$ & 0.0192 & $0.5454 * * *$ & 0.0677 & $0.3954 * * *$ & 0.0493 \\
BTS degree & $0.9142 * * *$ & 0.1446 & $0.7785 * * *$ & 0.1508 & $0.4858 * * *$ & 0.0648 \\
BACHELOR degree & $1.1649 * * *$ & 0.0654 & $1.9511 * * *$ & 0.3296 & 0.7204 & 0.0789 \\
MASTER and upper degrees & $1.5223 * * *$ & 0.1423 & $3.4313 * * *$ & 0.4280 & $3.0918 * * *$ & 0.0847 \\
\hline
\end{tabular}

Source: Author's calculations based on Table 2 .

In the Cameroon economy where the formal sector of the labour market is unable to grow at a fast enough pace to absorb the ever rising labour force, competition for the limited formal sector jobs is keen and people tend to invest more in education in order to get degrees that will enable them to get better paid jobs. As one can observe on table 3, highest marginal rate of 
return to additional certificates are obtained in the formal private sector. Graduating from the first level of the secondary education entails a marginal return of $2.54 \%$ for civil servants, $4.70 \%$ for formal private workers, and $5.53 \%$ for informal workers. Schooling two additional years after the GCE-AL increases wages by $6.6 .54 \%$ in the public sector and by $32.96 \%$ in the formal private sector; the increase is not statistically significant in the informal sector. It is worth mentioning that in the formal sector (public and private), returns to an additional year of tertiary education once the BTS certificate is obtained are lower than returns to an additional year after the GCE-AL. This result comes as an indication that holders of this vocational certificate are worse-off working with a Bachelor degree. It may also be interpreted as a result of the quadratic form of returns to additional years of schooling. The return to two additional years of tertiary education once the Bachelor degree is obtained tends to be relatively high in the formal private sector $(42.80 \%)$ followed by the public sector $(14.23 \%)$.

\section{Conclusion}

This study analyses the returns to education in Cameroon and uses the 2005 Employment and Informal Sector Survey. Two sample selection corrected wage equations are estimated for each labour market sector to check for a "parchment effect" in the urban Cameroon labour market. In line with findings in the literature on sub-Saharan Africa, results show that earnings rise with higher certificates in all sectors of employment. Completing a certificate is more beneficial than completing one year of college without a credential; a GCE-OL degree is more valuable than four years of college without the credential; the probation degree (Probatoire) increases earnings by more than two years of college after the GCE-OL without the certificate. This suggests that completing credentials is the wisest course for most individuals. Overall, returns to education in the formal private sector are higher than returns to education both in the public and informal sectors. Thus, it is more beneficial for those with high degrees to work in the formal private sector.

As a policy prescription from these results, the fact that those who do not graduate from a certain level of education cannot take advantage of the returns to this level calls for efforts to reduce classes repeating and school drop outs; there's a need to improve the internal efficiency of the Cameroon education system. The decrease in the returns to schooling between the BTS and the Bachelor degree provides some rationale for greater investment in schooling by private economic agents, beyond the one year needed to obtain the Bachelor degree. Further, public policies that enforce private initiative, in order to expand employment opportunities for underprivileged and socially excluded groups, must be encouraged as they benefit the whole society via the externalities of education.

\section{References}

Amin, A. A., \& Awung, W. J. (2005). Economic analysis of private returns to investment in education in Cameroon. Paper presented at the Regional Conference on Education in West Africa: Constraints and Opportunities, November 25-26, Dakar, Senegal.

Angrist, J. D. (1995). The economic returns to schooling in the West Bank and Gaza Strip. The American Economic Review, 85(5). 1065-1087. 
Appleton, S., Bigsten, A., \& Manda, D. K. (1999). Educational expansion and economic decline: Returns to education in Kenya, 1978-1995. Centre for the Study of African Economies Working Paper 6; Oxford.

Aromolaran, A. B. (2004). Wage returns to schooling in Nigeria. African Development Review, 16(3), 433-55. http://dx.doi.org/10.1111/j.1017-6772.2004.00099.x

Aromolaran, A. B. (2006). Estimates of Mincerian returns to schooling in Nigeria. Oxford Development Studies, 34(2), 265-89. http://dx.doi.org/10.1080/13600810600707433

Benhayoun, G., \& Bazen, S. (1995). Salaire-éducation au Maroc. Région et Développement, 1. Bennell, P. (1996). Rates of return to education: Does the conventional pattern prevail in sub-Saharan Africa? World Development, 24(1), 183-99. http://dx.doi.org/10.1016/0305-750X(95)00115-S

Bigsten A., Collier, P., Dercon, S., Fafchamps, M., Gauthier, B., Gunning, J. W., Isaksson, A., Oduro, A., Oostendorp, R., Pattillo, C., Soderbom, M., Teal, F., \& Zeufack, A. (2000). Rates of return on physical and human capital in Africa's manufacturing sector. Economic Development and Cultural Change, 48, 801-827. http://dx.doi.org/10.1086/452478

De Monchy, G., \& Roubaud, F. (1991). Cameroun: Evolution économique rétrospective et perspectives macroéconomiques à l'horizon de 1995. Etude DIAL, 2/E.

Emini, C. A., Cockburn, J., \& Decaluwe, B. (2005). The poverty impacts of the Doha round in Cameroon: The role of tax policy. MPIA Working Paper 04, Poverty and Economic Policy (PEP) Research Network, University of Laval, Quebec.

Ewoudou, J., \& Vencatachellum D. (2006). An empirical analysis of private rates of returns to education in Cameroon. Paper presented at the "7èmes journées scientifiques du réseau Analyse Economique et Développement de l'Agence Universitaire de la Francophonie » under the theme, Institutions, développement économique et transition, $7^{\text {th }}$ to $8^{\text {th }}$ September 2006 , Paris-France.

National Institute of Statistics (1996). Enquête Camerounaise auprès des ménages. Rapport Principal». Mimeo

National Institute of Statistics (2005). Enquête sur l'Emploi et le secteur informel au Cameroun (EESI). Phase 1: Enquête sur l'emploi. Rapport Principal ». Mimeo

Kimenyi, M. S., Mwabu, G., \& Manda, D. K. (2006). Human capital externalities and private returns to education in Kenya. Eastern Economic Journal, 32(3), 493-513.

Lanot, G., \& Muller, C. (1997). Dualistic sector choice and female labour supply: Evidence from formal and informal sectors in Cameroon. Center for the Study of African Economies Working Paper Series 9, University of Oxford, Oxford.

Lee, L. F. (1983). Generalized econometric models with selectivity. Econometrica, 51, 507-512. http://dx.doi.org/10.2307/1912003 


\section{Macrothink}

Business and Economic Research ISSN 2162-4860 2013, Vol. 3, No. 2

Liu, Z. (1998). Earnings, education, and economic reforms in urban China. Economic Development and Cultural Change, 46(4), 697-725. http://dx.doi.org/10.1086/452370

Manda D., \& Bigsten, A. (1998). Changes to returns to education overtime in Kenya. Mimeo CSAE, Oxford University, Oxford.

Mincer, J. (1974). Education, experience and earnings. New York: Columbia University Press.

Mincer, J., \& Polacheck, S. (1974). Family investments in human capital: Earnings of women. Journal of Political Economy, 82(2), S76-S108. http://dx.doi.org/10.1086/260293

Psacharopoulos, G. (1994). Returns to investment in education: A global update. World Development, 22(9), 1325-1343. http://dx.doi.org/10.1016/0305-750X(94)90007-8

Sackey, H. A. (2008). Private returns to education in Ghana: Implications for investments in schooling and migration. AERC Research Paper 174, African Economic Research Consortium, Nairobi, Kenya.

Schultz, T. (2004). Evidence of returns to schooling in Africa from household surveys: Monitoring and restructuring the market for education. Journal of African Economies, 13 (Supplement), 95-148. http://dx.doi.org/10.1093/jae/ejh044

Tafah-Edokat, E. O. (1998). Rates of return to education: A case of Cameroon. Unpublished paper, Department of Economics, University of Yaoundé II, Cameroon.

Tansel, A. (1999). Formal versus informal sector choice of wage earners and their wages in Turkey. Economic Research Forum Working Paper No. 9927, Cairo, Egypt.

Trost, R., \& Lee, L. F. (1984). Technical training and earnings: A polytomous model with selectivity. Review of Economics and Statistics, 66, 151-156. http://dx.doi.org/10.2307/1924708

Tsafack-Nanfosso, R. (2006). La dynamique de l'enseignement supérieur privé au Cameroun. Journal of High Education in Africa, 4(2). 99-122.

World Bank (1996). Cameroon: country assistance strategy. Report $\mathrm{n}^{\circ}$ 12275-CM. Washington, DC.: The World Bank.

\section{Endnotes}

\footnotetext{
i The University of Yaoundé, the sole university at that time, compounded the faculty of Law and Economics, the faculty of Arts and Social Sciences, and the faculty of Science. The Government also built professional and technological schools in order to prepare graduates for immediate integration into the public service or Government corporations. By 1967 other establishments were created and attached to the University of Yaoundé. The principal ones are the University Centre for Health Sciences (CUSS), the Institut de l'Administration des Entreprises (IAE), International School of Journalism (ESIJY), the Institute of International Relations (IRIC)
} 
and the National Advanced School of Engineering (ENSP). With the creation of these training capacities, the nation was finally poised to tackle the broad strategic problems of development.

ii CFAF represents the monetary unit used in Cameroon and in the countries that are members of the Central African Economic and Monetary Community. CFAF means Communauté Financière d'Afrique (that is African Financial Community)

iii During the second year, students sit an exam to get the Probation Degree named "Probatoire" which allow them sit the final exam of the secondary school, that is the Baccalauréat. Recall, the french name of the FLSC is Certificat d'Etudes Primaires et Élémentaires (CEPE), while the GCA-OL is named Brevet d'Etudes du Premier Cycle (BEPC).

iv Post secondary education is mainly provided by universities, specialized institutions and schools. University level studies are sanctioned by a Diplôme d'Etudes Universitaires Générales (DEUG) after two years, a Bachelor degree (also called Licence) one year after the DEUG a Maîtrise one year (in faculties of Economics and Management and in Law) or two years (in faculties of Arts and Sciences) after the Licence, and a doctorate (3 to 5 years after the Diplôme d'Etudes Approfondies (DEA), generally obtained one year after the Maitrise).

v Note, sample mean numbers are very close to these statistics. For instance, we have 5.098, 9.917 and 15.824 respectively for those who have the primary, the secondary and the tertiary levels of education. As far as the highest degree obtained is concerned, mean number of years of schooling are 7.640 for the FLSC/CEP degree, 10.621 for the GCE-OL/BEPC degree, 12.033 for the Probation degree, 13.364 for the GCE-AL/Bacalaureat degree, 15.086 for the BTS degree, 16.115 for the Bachelor/Licence degree, 17.996 for the Master and uppers degrees.

vi To compute these returns to experience, we used coefficients obtained in specification (2) and the formula used to compute these return is $\left(\exp \left(\alpha_{j}\right)-1\right)$.

\section{Copyright Disclaimer}

Copyright reserved by the author(s).

This article is an open-access article distributed under the terms and conditions of the Creative Commons Attribution license (http://creativecommons.org/licenses/by/3.0/). 